\title{
Topic Study Group No. 34: Social and Political Dimensions of Mathematics Education
}

\author{
Murad Jurdak, Renuka Vithal, Peter Gates, Elizabeth de Freitas \\ and David Kollosche
}

\section{Pre-Congress Activities}

The inclusion of a Topic Study Group (TSG 34) on social and political dimensions of mathematics education was a first under that title in ICME's history. Such recognition weighed on TSG 34 Team members to live-up to the challenge of organizing TSG 34. The Team spent quite some time trying to understand each other's perspectives and to formulate a mission statement that, on one hand, recognized the integrity of the perspectives of its members, and on the other hand was meaningful to the international mathematics education community. The intensive and lengthy deliberations led to a mission statement (reproduced in Section "TSG 34 Mission Statement" below) that was published in the 2nd ICME-13 Announcement.

Also TSG 34 decided to make use of ICME-13/Springer offer to publish a topical survey on the social and political dimensions of mathematics education. The Team collectively prepared a survey (Jurdak, Vithal, de Freitas, Gates, \& Kollosche, 2016) entitled 'Social and Political Dimensions of Mathematics Education-Current Thinking', a description of which is given in Section "TSG 34 Topical survey on 'Social and Political Dimensions of Mathematics Education-Current Thinking"'.

Co-chairs: Murad Jurdak, Renuka Vithal.

Team members: Peter Gates, Elizabeth de Freitas, David Kollosche.

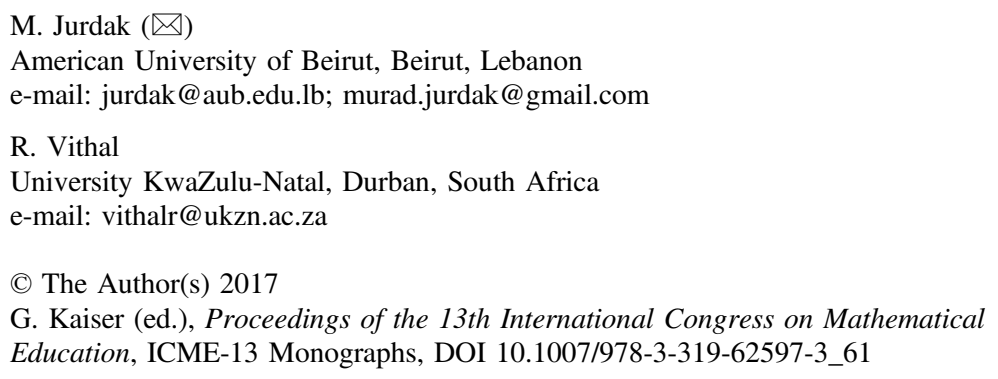




\section{TSG 34 Mission Statement}

TSG 34 will critically examine the social and political dimensions of mathematics education scholarship and practice. The Group will examine the different meanings of the constructs of 'social' and 'political' as they relate to mathematics education, attending to a diverse range of scales, from the global to the micro-political, and examining a diverse range of international contexts, particularly contexts characterized by poverty and conflict, 'liberation' movements, and immigration. The Group is preparing the 'Essentials', a pre-ICME13 publication, whose aim is to present an overview of research and open the discussions on concerns in mathematics education, such as issues of equitable access and quality education, the role of economic and historical factors, distributions of power and cultural regimes of truth, dominant and counter discourses around identity and dis/ability, and activism and material conditions of inequality. In addition, the Essentials will examine salient implications of these concerns to domains such as: curriculum and reforms; learning and cognition; nature and measures of student outcomes; teaching and teacher education; media and digital technologies; research practice and impact. A Facebook Page and a Facebook group has been set up for TSG34, both called ICME13 TSG34 Social and Political Dimensions of Mathematics Education. A call for papers dealing with, but not limited to, the themes of the Essentials will be advertised. During the Congress, the Group will provide a variety of interactive formats for conveying and discussing relevant issues including invited lectures, plenary panels, presentations of accepted papers and posters and small group discussions.

\section{TSG 34 Topical Survey on 'Social and Political Dimensions of Mathematics Education-Current Thinking'}

The authors of 'Social and Political Dimensions of Mathematics Education-Current Thinking' (Jurdak et al., 2016) ruled out a conventional survey of literature on the social and political dimensions of mathematics education and opted to focus on what they considered five critical areas of the social and political dimensions of mathematics education:

- Equitable access and participation in quality mathematics education: ideology, policies, and perspectives

- Distributions of power and cultural regimes of truth

- Mathematics identity, subjectivity and embodied dis/ability

- Activism and material conditions of inequality

- Economic factors behind mathematics achievement.

Furthermore, the team opted to focus mainly on current thinking in those five areas and only to go back in history as far as was needed to contextualize the 
current issues. Each author took primary responsibility for writing one of the sections and for reviewing one section written by another author.

Based on a critical review of current thinking in five selected areas, the survey found that (1) equitable access and participation in mathematics education is achievable in some countries; (2) mathematics is increasingly perceived as a negotiable field of social practices arising from specific needs and serving certain interests; (3) research seems to re-entrench stereotypes about identities that excel at mathematics and tends to assume a binary between structure and agency; (4) the relations between activism, the material conditions of inequality and mathematics education has remained under-developed and under-represented; and, (5) the nature of a society's economic structure influences relations in a classroom and may lead to a marginalisation of mathematics learners, specifically those from poor and working class households.

\section{Implemented Programme}

The programme was delivered in four 90-minutes sessions, distributed over four days. The first and last days had one 90-minutes session each, while the second and third days had two parallel 90-minutes sessions each.

\section{First Day}

The 90-minutes session was an openinning session, which was chaired by Renuka Vithal and Murad Jurdak and included two events. The first event included a welcome and program overview, self-introductions by Group members, and introduction of the Topical Survey on Social and Political Dimensions of Mathematics Education-current thinking. The second event was a panel which was chaired by Elizabeth de Freitas and David Kollosche and entitled (conceptions of social and political dimensions of mathematics education). The panel featured four panalists: Paola Valero, Lisa Darragh, Renuka Vithal, Murad Jurdak.

\section{Second Day}

The second day included two parallel sessions each of $90 \mathrm{~min}$. The first parallel session was chaired by Renuka Vithal and had the theme of activism and material conditions of inequality. The session included four presentations. The first presentation titled 'Teaching Mathematics for Social Justice Here And There: Teacher Candidates' Reactions In The United States and Uruguay' was given by Paula Patricia Guerra Lombardi on behalf of her co-authors Wooing Limand and 
Hyunjung Kang. The second presentation titled 'Nomadic Topologies Change Mathematics Educators' Subjectivities and Hence Their Worlds' was given by Peter Appelbaum. The third presentation titled 'Financial Education and Mathematics Education: A Critical Approach' was given by Celso Ribeiro Campos on behalf of his co-author Aurelio Hess. The last session titled '”Its Influence Taints All": Mathematics Teachers Resisting Performativity through Engagement with the Past' was given by Gill Adams on behalf of her co-authors Hilary Povey and Rosie Everley.

The second parallel session which was chaired by David Kollosche had the theme of "distributions of power and cultural regimes of truth" and included five presentations. The first presentation titled 'Truths and Powers in Mathematics Education' was given by Alexandre Pais, an invited speaker. The second presentation titled 'The Ethics of Mathematical Application and the Ideology of Solutionism' was given by Hauke Straehler-Pohl. The third presentation titled 'Outcome of The Market Logic: The Academic-Professional Development of the Mathematics Teacher' was given by Alex Rodrigo Montecino Muñoz. The fourth presentation titled 'Enacting Hybridity in a Home-school Mathematics Activity' was given by Laura Black on behalf of her co-authors Sophina Choudry, Kelly Pickard-Smith, Bethany Ryan, and Julian Williams. The fifth presentation titled 'Mathematics, the Axiomatization Movement, and its social Implications' was given by Sabrina Bobsin Salazar.

\section{Third Day}

The third day included two parallel sessions each of $90 \mathrm{~min}$. The first parallel session was chaired by Murad Jurdak and had the theme of 'equitable access and participation in quality mathematics education: ideology, policies, and perspectives. The session included five presentations. The first presentation titled 'Mathematics Curricula: Issues of Access and Quality' was given by Tamsin Meaney, an invited speaker. The second presentation titled 'Mathematics Education for Social Justice: A Case Study' was given by Natalia Ruiz López on behalf of her co-authors Gustavo Bruno, César Sáenz de Castro, and José Bosch Betancor. The third presentation titled 'Social, Political, Personal, and Imagined Constraints on Enacting Change after Professional Development' was given Lisa Jean Darragh. The fourth presentation titled "The Production of "Common Sense" in the Media about More Mathematics in Early Childhood Education' was given by Troels Lange on behalf of his co-author Tamsin Meaney. The fifth presentation titled 'The Influence of Habitual Dispositions according to Pierre Bourdieu in Handling Mathematical Problems' was given by Belgüzar Kara.

The second parallel session was chaired by Elizabeth de Freitas and had the theme of 'Mathematics identity, subjectivity and embodied dis/ability'. The session included four presentations. The first presentation titled 'Parody and Power: Producing and Resisting Mathematics 'Ability" was given by Yvette Solomon, an 
invited speaker. The second presentation titled 'Maths Moves Me: The Body as a Political Space for Learning' was given by Anna Chronaki. The third presentation titled 'Unequal Bodies-Corporeality and Social Inequality in the Context of Mathematics Education' was given Nina Bohlmann. The fourth presentation titled 'The Biopolitics of Number Sense: Ordinality and Ontology' was given by Elizabeth de Freitas on behalf of her co-author Nathalie Sinclair.

\section{Fourth Day}

The session of the fourth day which was chaired by Murad Jurdak and Renuka Vithal included open whole-group discussion on four topics:

1. Open discussion on economic dimension of mathematics education

2. Reporting back from parallel sessions

3. Open discussion on the implications of social and political dimensions of mathematics education.

4. Group wrap-up.

\section{Concluding Remarks}

1. There was an appreciation on the part of the Team members of the collaborative work among them, though they came from different perspectives on social and political dimensions of mathematics education.

2. There was a general feeling on the part of the Team as well as participants that the programme was well planned and efficiently executed.

3. There was a consensus that the economic dimension of mathematics education should be added to the social and political dimensions as a distinct dimension of mathematics education in future ICME's.

4. There was a general agreement to recommend that the TSG on the social and political dimensions of mathematics education be included in future ICME's. The relevance and significance of this Study Group was evidenced by the number, richness, and scholarly and cultural diversity of the presented papers. 


\section{Reference}

Jurdak, M., Vithal, R., de Freitas, E., Gates, P., \& Kollosche, D. (2016). ICME 13 Topical Surveys series, social and political dimensions of mathematics education-current thinking. Cham: Springer Open.

Open Access Except where otherwise noted, this chapter is licensed under a Creative Commons Attribution 4.0 International License. To view a copy of this license, visit http://creativecommons. org/licenses/by/4.0/.

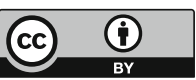

